\title{
A new adult AML case with an extremely complex karyotype, remission and relapse combined with high hyperdiploidy of a normal chromosome set in secondary AML
}

Abdulsamad Wafa', Suher ALmedania', Abdulmunim Aljapawe², Thomas Liehr ${ }^{3}$, Soulaiman E. Soulaiman ${ }^{4}$, Raja Mouna ${ }^{4}$, Moneeb A. K. Othman ${ }^{3}$ and Walid ALachkar ${ }^{1 *}$

\begin{abstract}
Background: Chromosomal abnormalities are diagnostic and prognostic key factors in acute myeloid leukemia (AML) patients, as they play a central role for risk stratification algorithms. High hyperdiploidy $(\mathrm{HH})$, a rare cytogenetic abnormality seen commonly in elder male AML patients, is normally categorized under AML with complex karyotype (CK). Accordingly, patients with $\mathrm{HH}$ generally are associated with low remission rates and a short overall survival.

Case presentation: Here we report a case of 21-year-old female, diagnosed with a de novo AML-M1 according to WHO classification and a CK at diagnosis. Cytogenetic, molecular cytogenetic approaches (standard fluorescence in situ hybridization (FISH), array-proven multicolor banding (aMCB)) and high resolution array comparative genomic hybridization $(\mathrm{aCGH})$ analyses revealed a unique complex but still near diploid karyotype involving eleven chromosomes was identified. It included pentasomy 4, three yet unreported chromosomal aberrations $t(1 ; 2)(\mathrm{p} 35 ; \mathrm{p} 22)$, $\mathrm{t}(1 ; 3)(\mathrm{p} 36.2 ; \mathrm{p} 26.2)$, and $\mathrm{t}(10 ; 12)(\mathrm{p} 15.2 ; \mathrm{q} 24.11)$, and a combination of two cytogenetic events, yet unreported to appear in together, i.e. a reciprocal translocation t(1;3)(p36.2;p26.2) leading to EVI1/PRDM16 gene fusion, and monoallelic loss of tumor suppressor gene TP53. After successful chemotherapeutic treatment the patient experienced a relapse to AMLM1, and she developed secondary AML-M6 with tetraploidy and HH. Unfortunately, the young woman died 8. 5 months after initial diagnosis.

Conclusions: To the best of our knowledge, a comparable adult AML associated with such a CK, coexistence of $3 q$ rearrangements with loss of TP53 at diagnosis, and HH in secondary AML were not previously reported. Thus, the combination of the here seen chromosomal aberrations in adult primary AML seems to indicate for an adverse prognosis.
\end{abstract}

Keywords: Acute myeloid leukemia, Complex karyotype, High hyperdiploidy, Pentasomy 4, Molecular cytogenetics, Array comparative genomic hybridization (aCGH), Prognostic factors

\section{Background}

Acute myeloid leukemia (AML) may be observed in children and/or adult patients. It is well established, that acquired chromosomal rearrangements play a central role in risk stratification of the disease [1-4]. Accordingly, the European Leukemia Net (ELN) recommendations

\footnotetext{
* Correspondence: ascientific@aec.org.sy

${ }^{1}$ Department of Molecular Biology and Biotechnology, Human Genetics

Division, Atomic Energy Commission, Damascus, Syria

Full list of author information is available at the end of the article
}

[5] classified specific, repeatedly observable chromosomal abnormalities according to prognoses as

- favorable - e.g. $\mathrm{t}(8 ; 21)(\mathrm{q} 22 ; \mathrm{q} 22), \mathrm{t}(15 ; 17)(\mathrm{q} 21 ; \mathrm{q} 21)$, inv.(16)(p13q22)\}

- intermediate - e.g. $\mathrm{t}(9 ; 11)(\mathrm{p} 22 ; \mathrm{q} 23)$, or

- adverse - e.g. -5 or $\operatorname{del}(5 q),-7$ or $\operatorname{del}(7 q)$, abnormalities of 3q, abnormalities of $17 p$, translocations $\mathrm{t}(9 ; 22)(\mathrm{q} 34 ; \mathrm{q} 11)$, translocation $\mathrm{t}$ (v;11q23.3), complex karyotype (CK) and near haploid karyotype.

(c) The Author(s). 2018 Open Access This article is distributed under the terms of the Creative Commons Attribution 4.0 International License (http://creativecommons.org/licenses/by/4.0/), which permits unrestricted use, distribution, and 
Approximately 10 to $15 \%$ of AML patients had a CK $[1,2,4,6,7]$, which have been associated with a poor prognosis, but were defined differently as the presence of $\geq 3$ and/or $\geq 5$ chromosome aberrations $[1,2,4,6,7]$. CKs, at the cytogenetic level are very heterogeneous and many studies have suggested new definitions based on affected regions or types of aberrations [2, 8].

High hyperdiploidy (HH) (i.e. $\geq 49$ chromosomes with or without additional structural rearrangements) is a very rare event observed in small subset of adult AML $(<2 \%)$ only $[9,10]$; it is primarily seen in de novo AML and older male patients with low remission rate and short survival [9]. Interestingly, Chilton et al. [11] indicated that not all HH-AML patients should be automatically classified as having adverse prognosis. Only those patients with the presence of other specific adverse cytogenetic features (for example, -5 or $5 q_{-}^{-},-7$ or $7 q_{-}^{-}$, abnormalities of 3q, translocation $\mathrm{t}(9 ; 22)$ and certain $M L L$ translocations) can confidently be assigned to the adverse risk group, whereas those with numerical changes only, should be classified into the intermediate risk group [11].

We present here for the first time a de novo adult AML case with a yet unreported complex karyotype involving eleven chromosomes at diagnosis and a subsequent tetraploidy and $\mathrm{HH}$ without all the previously observed changes in a secondary AML.

\section{Case presentation}

A 21-year-old female patient without any known adverse medical background presented with a 1 month history of headache, nausea, fatigue and blurred vision. Physical examination and computer tomographic (CT) scan showed pericardial inflammation and splenomegaly $(2 \mathrm{~cm})$. Ophthalmoscopy of the right eye revealed papillary edema, retinal hemorrhages (Roth's spots) and arteriovenous nickings (for further details see Fig. 1 and Table 1). Initial laboratory evaluation of peripheral blood (PB) revealed a white blood cells (WBC) of $113.2 \times 10^{9} / 1(72 \%$ were blasts), red blood cells (RBC) count was $2.53 \times 10^{6} /$ $\mathrm{mm}^{3}$, with a hemoglobin level of $9 \mathrm{~g} / \mathrm{dl}$ and a platelet count (Plt) of $61 \times 10^{9} /$ l. Prothrombine time was $15.1 \mathrm{~s}$ (normal value 10.0-13.0 s) while partial thromboplastin time (PTT) was $25.8 \mathrm{~s}$ (normal value $29 \pm 3.5 \mathrm{~s}$ ). Creatinine value showed $38.7 \mu \mathrm{mol} / \mathrm{l}$ (normal $45-120$ ) and uric acid value $498.2 \mu \mathrm{mol} / \mathrm{l}$ (normal 150-450). Bone marrow (BM) aspiration revealed 70\% of blasts (Fig. 2).

At this point the first cytogenetic and immunophenotypic data were determined. Flow cytometric (FCM) analysis classified this case as AML-M1. The patient was

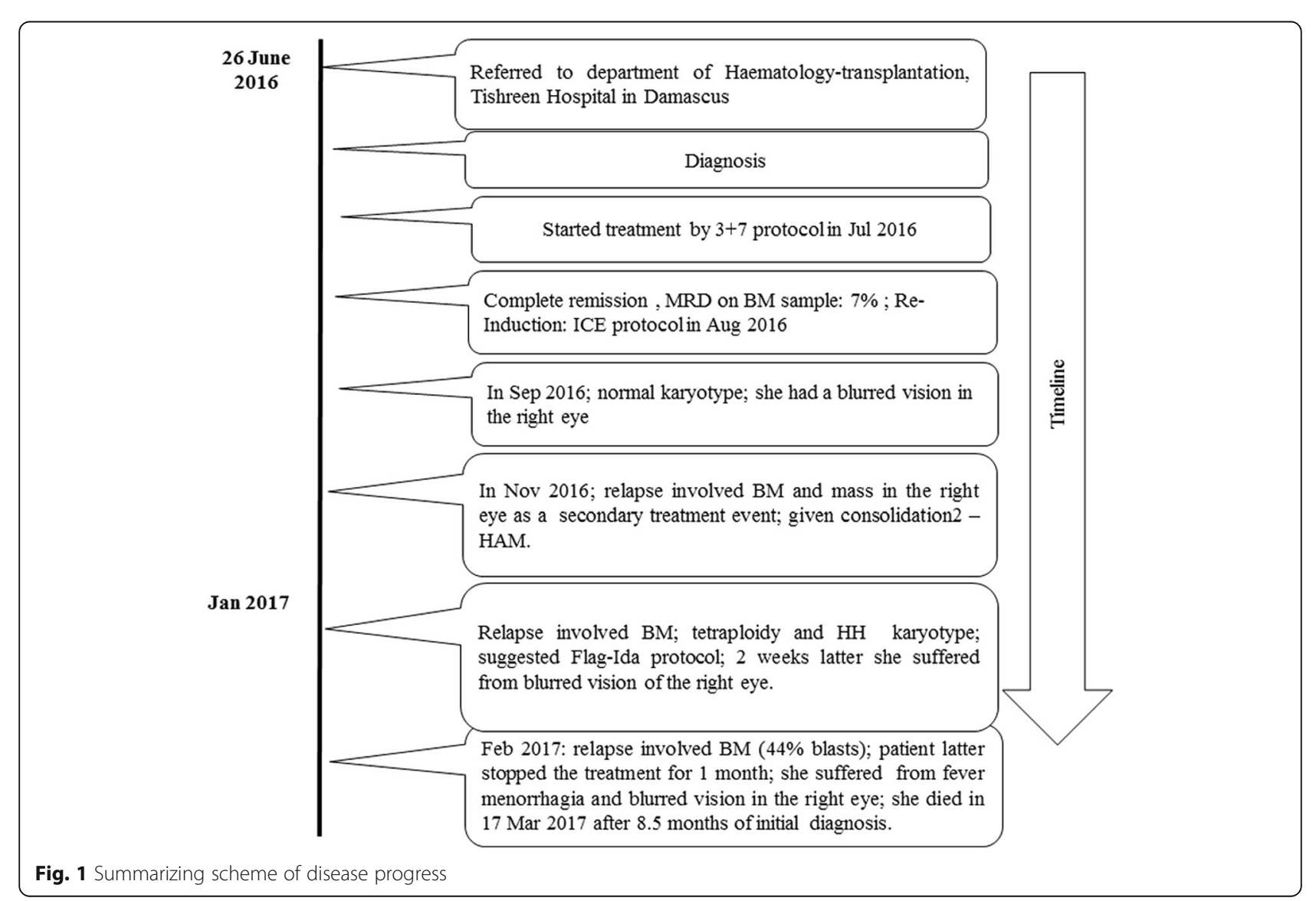




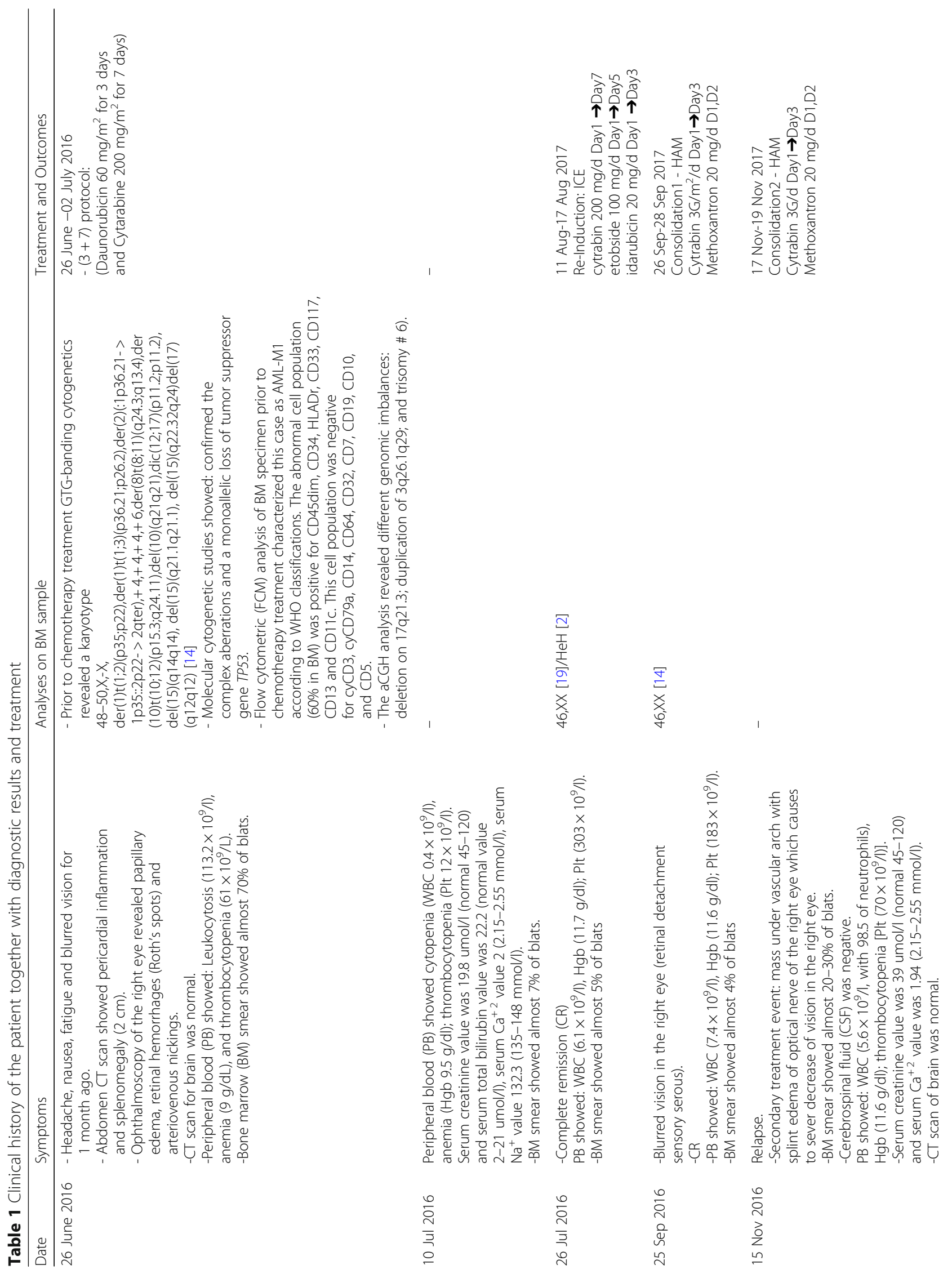




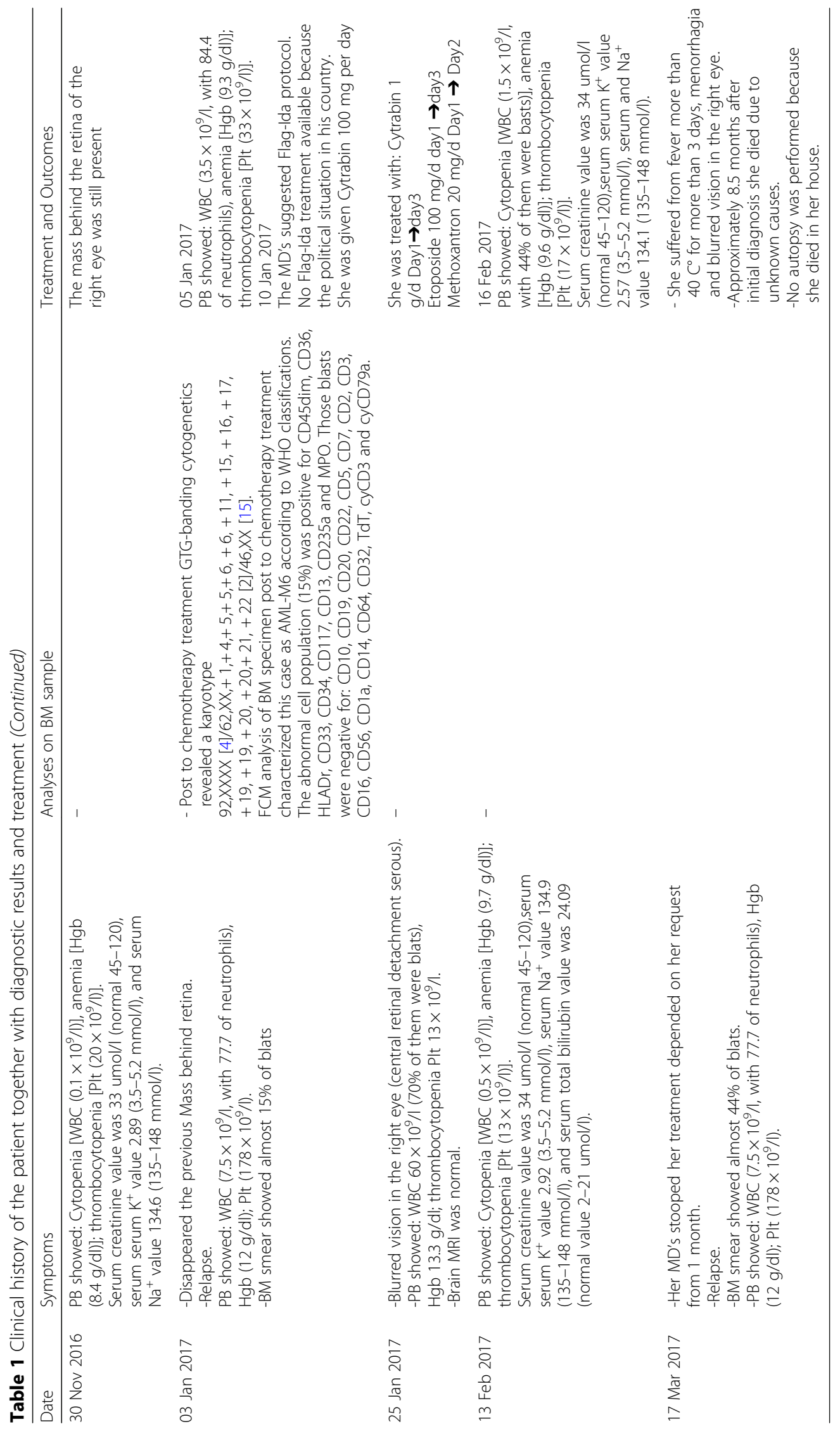




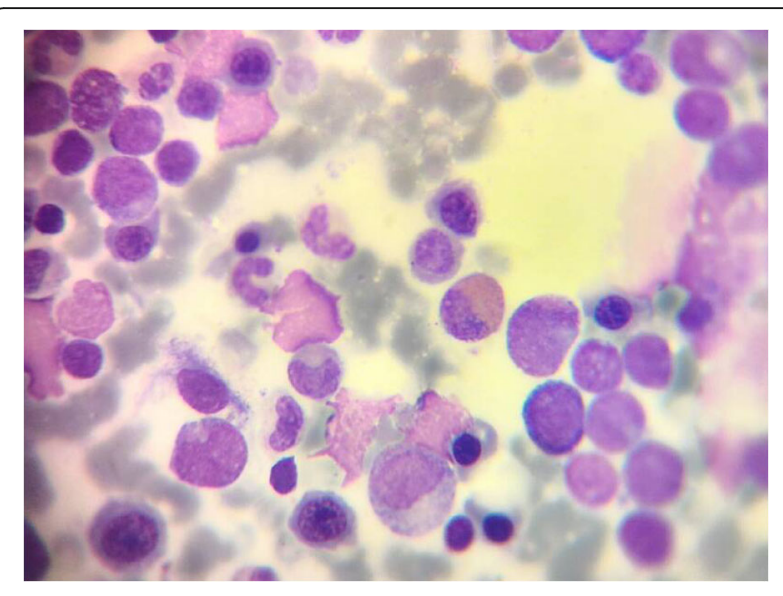

Fig. 2 Bone marrow smears of an acute myeloid leukemia without maturation case showing numerous blasts with round nuclei, fine nuclear chromatin, and dark blue cytoplasm (Leishman stain, oil immersion $\times 100$ )

given standard treatment for AML including $(3+7)$ induction chemotherapy (Daunorubicin $60 \mathrm{mg} / \mathrm{m}^{2}$ for 3 days and Cytarabine $200 \mathrm{mg} / \mathrm{m}^{2}$ for 7 days). On day + 28 of treatment with $(3+7)$ protocol, the patient had not responded as expected to the treatment, i.e. her $\mathrm{PB}$ revealed pancytopenia/cytopenia (WBC $0.4 \times 10^{9} / \mathrm{l}$ ), anemia (hemoglobin level $=\mathrm{Hgb}: \quad 9.5 \mathrm{~g} / \mathrm{dl}$ ); thrombocytopenia (Plt $12 \times 10^{9} / \mathrm{l}$ ) and less than $7 \%$ blasts in BM aspiration. The patient was given re-induction chemotherapy (ICE protocol: Cytrabin $200 \mathrm{mg} /$ day: day $1 \rightarrow$ day 7, Etobside $100 \mathrm{mg} /$ day: day 1 $\rightarrow$ day 5 , and Idarubicin $20 \mathrm{mg} /$ day: day $1 \rightarrow$ day 3 ) and she achieved complete remission on day 30 of ICE protocol treatment (WBC $7.4 \times 10^{9} / \mathrm{l}$; Hgb $11.6 \mathrm{~g} / \mathrm{dl}$; Plt $183 \times 10^{9} / \mathrm{l}$ ), with less than $4 \%$ blasts in BM aspiration. Still the patient suffered from blurred vision in the right eye (retinal detachment sensory serous) during ICE protocol treatment but her karyotype was normal. The patient was given consolidation I chemotherapy (High dose Ara-C = HIDAC: Cytarabine $3 \mathrm{~g} / \mathrm{m}^{2} /$ day; day $1 \rightarrow$ day 3; and Methoxantron $20 \mathrm{mg} /$ day; day $1 \rightarrow$ day 2). Afterwards the patient did not return to the hospital to continue the treatment for 6 weeks. Then she was referred to the hospital again for blurred vision in the right eye and a mass under the vascular arch with splint edema of optical nerve of the right eye was diagnosed, being the cause of her severe decrease in vision. While cerebrospinal fluid (CSF) test was negative, BM aspiration revealed $20-30 \%$ of blasts. In PB WBC was $5.6 \times$ $10^{9} / 1$ (98.5\% of neutrophils), Hgb was $11.6 \mathrm{~g} / \mathrm{dl}$, Plt of $70 \times 10^{9} / 1$ indicated for thrombocytopenia while CT scan of brain was normal. Now she treated with consolidation II chemotherapy (HIDAC), 2 weeks later her $\mathrm{PB}$ had WBC $0.1 \times 10^{9} / \mathrm{l}$, Hgb $8.4 \mathrm{~g} / \mathrm{dl}$ and Plt still $20 \times 10^{9} / \mathrm{l}$; the mass behind the retina of the right eye was still present.
About 2 months later the patient relapsed and the following values were found: in PB WBC was $7.5 \times 10^{9} / 1$ with $77.7 \%$ of neutrophils, Hgb 12 was g/dl and Plt was $178 \times$ $10^{9} / \mathrm{l}$; BM aspiration revealed $15 \%$ of blasts. The MD's suggested to apply now the Flag-Ida protocol; however, due to the political situation in her home country only available treatment at this point was treatment with Cytrabin $100 \mathrm{mg} /$ day. Again 2 weeks later the patient suffered from blurred vision of the right eye due to serious central retinal detachment; her PB revealed a WBC of $60 \times 10^{9} / 1$ (70\% of them were blasts), $\mathrm{Hgb}$ of $13.3 \mathrm{~g} / \mathrm{dl}$; thrombocytopenia with Plt of $13 \times 10^{9} / 1$ was present with a normal brain MRI. Now the patient treated with Cytrabin $1 \mathrm{~g}$ /day: day $1 \rightarrow$ day 3, Etoposide $100 \mathrm{mg} /$ day: day 1 $\rightarrow$ day 3 , and Methoxantron $20 \mathrm{mg}$ /day: day $1 \rightarrow$ day 2 ).

Ten days later, the patient relapsed; her PB shows cytopenia [WBC $1.5 \times 10^{9} / 1$ with $44 \%$ blasts)], anemia (Hgb $9.6 \mathrm{~g} /$ $\mathrm{dl}$ ) and thrombocytopenia (Plt $\left.17 \times 10^{9} / \mathrm{l}\right)$. Now the patient stopped the treatment on her own request for 1 month. Afterwards she suffered from fever (more than $40{ }^{\circ} \mathrm{C}$ for more than 3 days), menorrhagia and blurred vision in the right eye. Approximately 8.5 months after initial diagnosis she died in her house and no autopsy was performed. Her husband agreed with scientific evaluation of her case and the study was approved by the ethical committee of the Atomic Energy Commission, Damascus, Syria.

Conventional cytogenetics analysis on unstimulated BM sample according to standard procedures was performed [12] prior and post chemotherapy treatments. Karyotypes according to the International System for Human Cytogenetic Nomenclature were classified [13].

Prior to chemotherapy treatment: GTG-banding cytogenetics revealed the following karyotype:

48-50,X,- X,der(1)t(1;2)(?;?), der(1)t(1;3)(?;?),+ 4,+ 4,+ 4,+ 6,t(8;11)(?;?),t(10;12)(?;?),dic(12;17)(?;?)× 2 [14] (Fig. 3), which was further specified by molecular cytogenetic studies (Figs. 4 and 5). Fluorescence in situ hybridization (FISH) using (WCP) probes for chromosomes 1, 2, 3, 4, 5, 6, 9, 12, 17 and X (MetaSystems, Altlussheim, Germany), a specific probe for ETV6 break apart probe and a specific probe for 17p13 (TP53) (Q-Biogene, USA) were applied according to manufacturer's instructions. Array-proven multicolor banding (aMCB) probes sets for chromosomes 1, 2, 3, 8, 10, 11, 12 and 17 were used [12]. Thus, the following final karyotype prior to chemotherapeutic treatment was determined using a fluorescence microscope [12]. 48-50,X,-X,der(1)t(1;2)(p35;p22), der(1)t(1;3)(p36.21;p2 6.2), $\operatorname{der}(2)(: 1 \mathrm{p} 36.21$ - > 1p35::2p22- > 2qter $),+4,+4,+4,+$ 6,der(8)t(8;11)(q24.3;q13.4),der(10)t(10;12)(p15.3;q24.11) ,del(10)(q21q21),dic(12;17)(p11.2;p11.2), del(15)(q14q14), $\operatorname{del}(15)(q 21.1 q 21.1), \operatorname{del}(15)(q 22.32 q 24) \operatorname{del}(17)(q 12 q 12)$

[14]. 


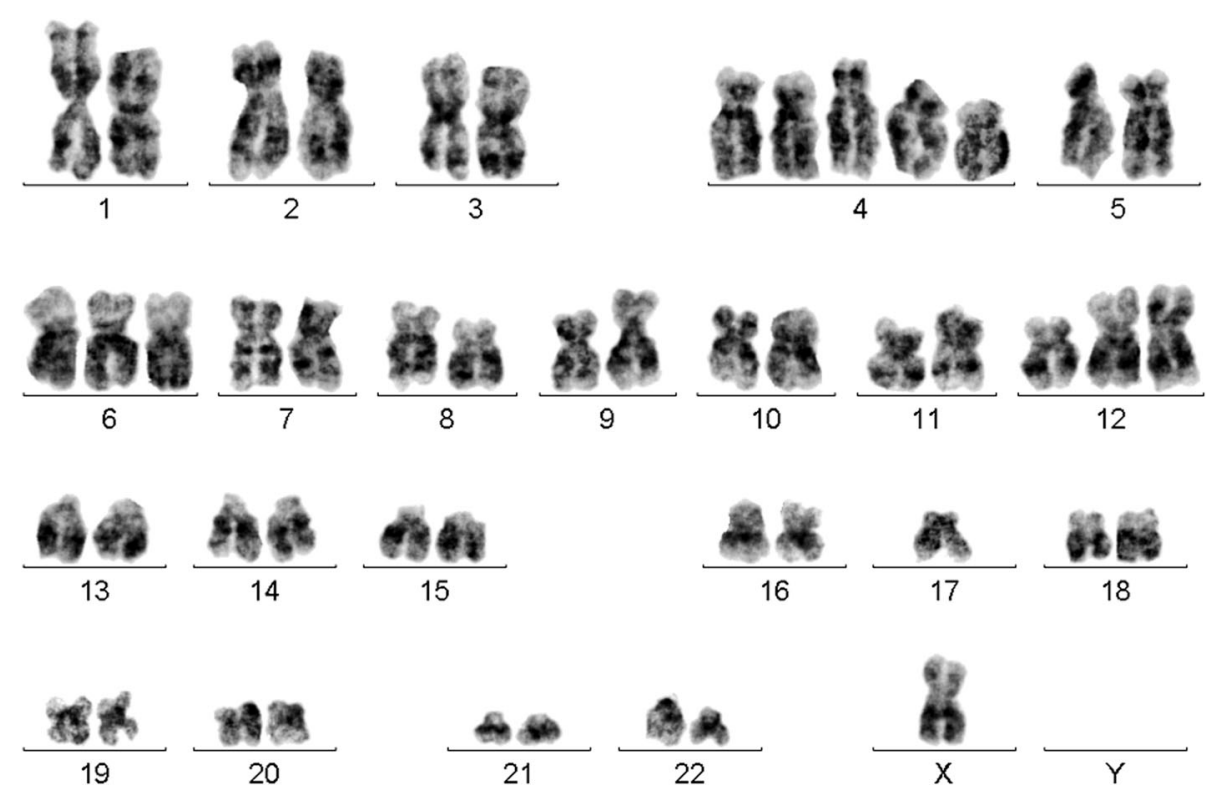

Fig. 3 GTG-banding revealed a hyperdiploid karyotype multiple numerical and or structural rearrangements

Genomic DNA was extracted from BM cells prior to chemotherapy treatment as previously reported [15]. aCGH was performed using the Agilent Sure Print G3 Human Genome Microarray $180 \mathrm{~K}$ as previously described [15]. The aCGH analysis revealed different genomic imbalances (Fig. 6). Thus, copy number alterations (CNAs) could be grouped according to their sizes as follows:

Focal CNAs (e.g. deletion on 14q14.3); CNAs involving variable numbers of genes (e.g. deletion on 17q21.3); CNAs involving large parts of chromosomal $\mathrm{p}$ or $\mathrm{q}$ arms

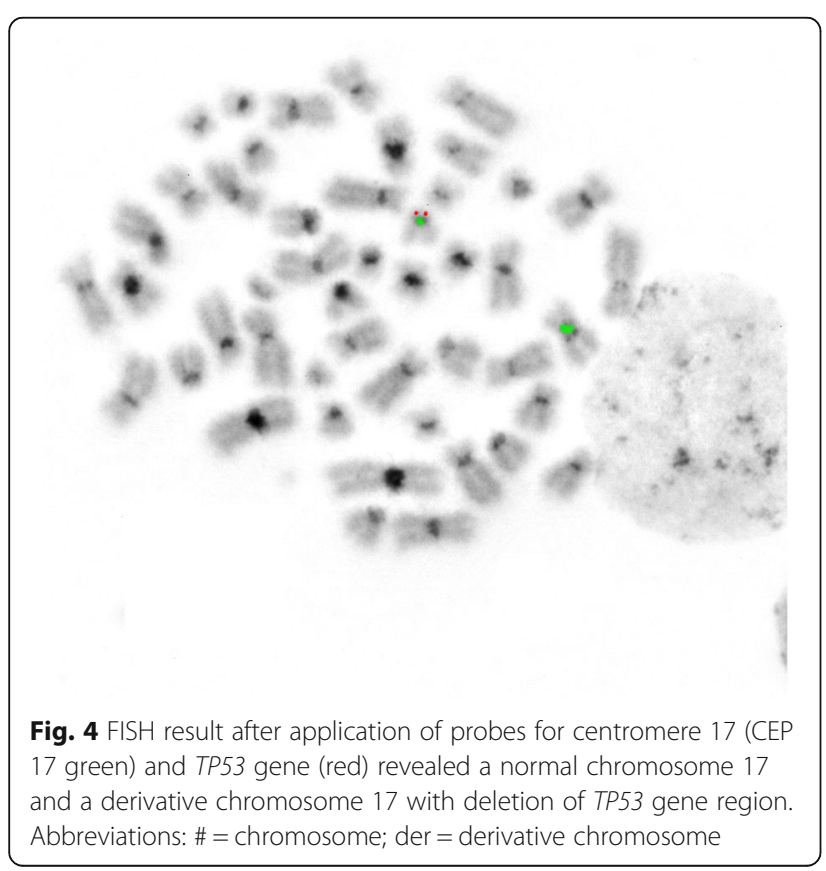

(e.g. duplication of 3q26.1q29) and CNAs of whole chromosomes (e.g. trisomy \# 6 -Table 2).

Immunophenotyping was performed on BM specimen prior and after chemotherapy treatment using a general panel of fluorescent antibodies against antigens typical for different cell lineages and cell types [16]: CD1a, CD2, CD3, CD4, CD5, CD8, CD10, CD11b, CD11c, CD13, CD14, CD15, CD16, CD19, CD20, CD22, CD23, CD32, CD33, CD34, CD36, CD38, CD41a, CD45, CD56, CD57, CD64, CD79a, CD103, CD117, CD123, CD138, CD209, CD235a and CD243; In addition to antibodies to Kappa and Lambda light Chains, IgD, sIgM, and HLADr. All antibodies were from BD Biosciences. Flow cytometric data acquisition and analysis were conducted [17]. FCM analysis of BM specimen prior to chemotherapy treatment characterized this case as AML-M1 according to WHO classifications. The abnormal cell population (60\% of tested cells) was positive for CD45 ${ }^{\mathrm{dim}}$, CD34, HLADr, CD33, CD117, and CD13. Blast cell population was negative for CD3, CD79a, CD14, CD64, CD32, CD7, CD19, CD10 and CD5.

After chemotherapy and relapse GTG-banding revealed a mosaic of tetraploidy and $\mathrm{HH}$ as 92,XXXX [4]/ $62, \mathrm{XX},+1,+4,+5,+5,+6,+6,+11,+15,+16,+17,+19,+$ $19,+20,+20,+21,+22$ [2]/46,XX [15] (Figs 7 and 8).

FCM analysis of BM specimen post to chemotherapy treatment characterized this case as AML-M6 according to WHO classifications. The abnormal cell population (15\%) was positive for CD45 ${ }^{\mathrm{dim}}$, CD36, HLADr, CD33, CD34, CD117, CD13, CD235a and MPO. Those blasts were negative for: CD10, CD19, CD20, CD22, CD5, CD7, CD2, CD3, CD16, CD56, CD1a, CD14, CD64, CD32, TdT, cyCD3 and cyCD79a. 


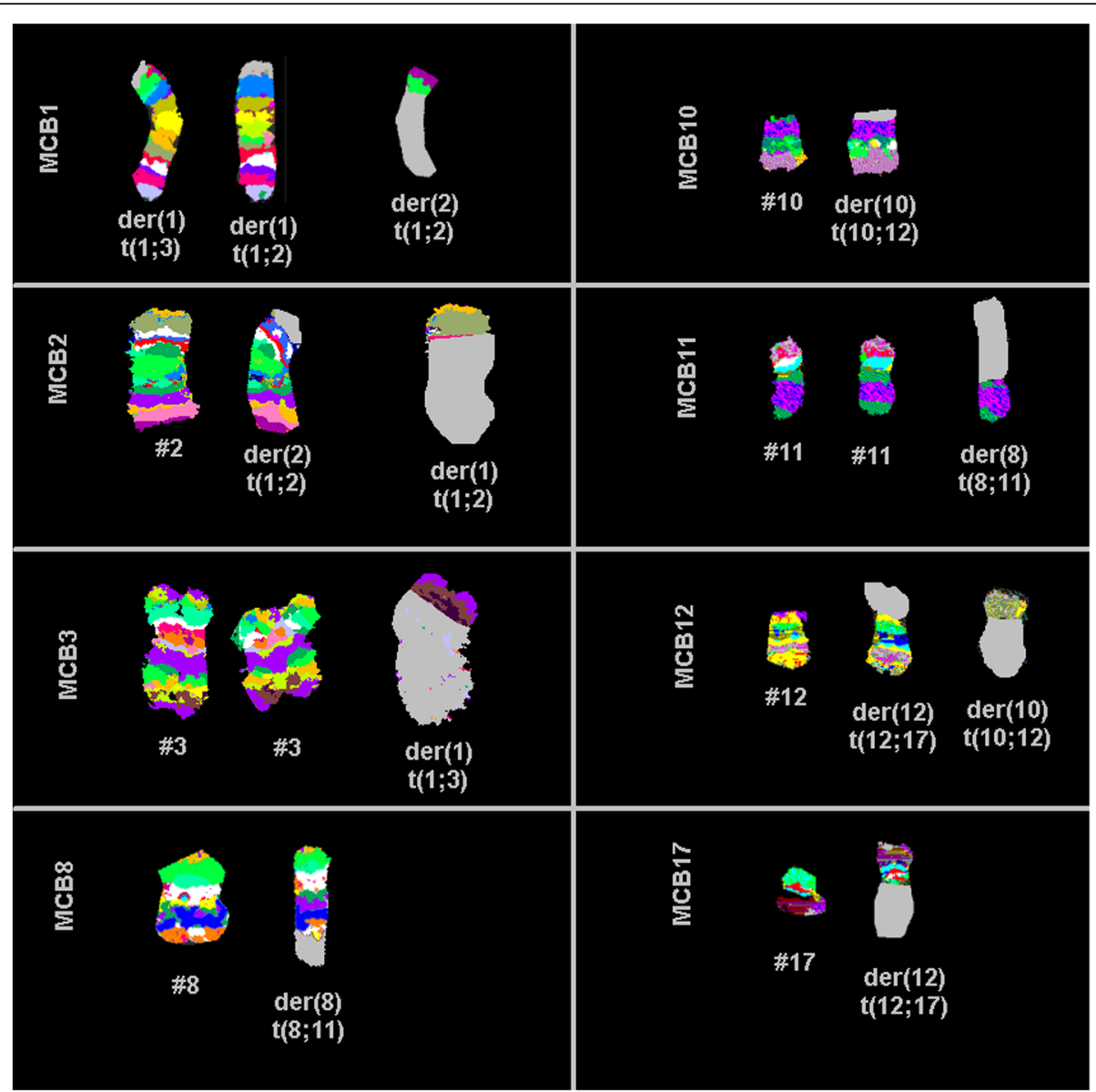

Fig. 5 aMCB results are shown. If available, the normal chromosomes (\#) are depicted on the left side and the derivative of the corresponding chromosomes on the right side of normal chromosomes. The unstained regions when using chromosome-specific aMCB-probe sets on the derivative chromosomes are shown in gray. \#= chromosome; der = derivative chromosome

\section{Discussion and conclusions}

To the best of our knowledge we report here the first case of a patient with an AML-M1 relapsing with a secondary AML-M6. In AML-M1 the patient presented a CK involving eleven chromosomes and yet unreported acquired chromosomal aberrations, while in AML-M6 a completely different, two-clonal karyotype with tetraploidy and $\mathrm{HH}$ was observed.

According to the literature, $\mathrm{HH}$ ( $\geq 49$ chromosomes) and tetraploidy ( $4 n=92$ chromosomes) has been reported to date in 15 and 99, respectively, of 18,334 AML cases listed in Mitelman database [18]. A translocation $t(1 ; 2)$ involving short and/or long arms of these chromosomes has been seen to date in 38 AML cases [18]. Also, deletion a part of the short arm of derivative chromosome 17 , translocation $\mathrm{t}(1 ; 3)$, translocation $\mathrm{t}(8 ; 11)$, translocation $\mathrm{t}(10 ; 12)$, deletion $\operatorname{del}(10)(\mathrm{q} 21), \operatorname{del}(15)(\mathrm{q} 21), \operatorname{del}(15)(\mathrm{q} 22 \mathrm{q} 24)$ and $\operatorname{dic}(12 ; 17)$ were previously reported in 3, 91, 10, 18, 1, 4, 1 and 7 AML cases, respectively [18]. Also, tetrasomy of chromosomes 4, 6,19 and 20 were previously reported in $4,18,22$ and 7 AML cases, respectively [18]. Interestingly, translocation $\mathrm{t}(1 ; 2)(\mathrm{p} 35 ; \mathrm{p} 22), \quad \mathrm{t}(1 ; 3)(\mathrm{p} 36.2 ; \mathrm{p} 26.2), \quad \mathrm{t}(10 ; 12)(\mathrm{p} 15.2 ; \mathrm{q} 24.11)$, $\operatorname{del}(17)(q 12 q 12)$, and pentasomy of chromosome 4 have never been described in AML cases. To the best of our knowledge, a combination of all these rearrangements in one AML case at diagnosis was not previous reported yet, also [18].

Gains of chromosomes, in particular tetrasomies 4, 8, $13,14,20$ and 21, as well as pentasomies 13, 21 and 22, have been observed in AML rarely. However, there was no influence on survival observed according to the number or types of trisomies or tetrasomies [19]. Also, tetraploidy (4n, 92 chromosomes) has not previously been reported in secondary AML cases; only Harrison et al. [20] described a hypotetraploid case in a secondary AML, which had an adverse outcome.

In general, $\mathrm{HH}$ and tetraploidy appears infrequently in AML; it seen primarily in de novo disease in older male patients ( $>60$ years) with low remission rates and short overall survival (OS) $[9,10]$. Unfortunately only limited data on incidence and clinical implications of $\mathrm{HH}$ and tetraploidy in AML is available. Still, most of comparable 


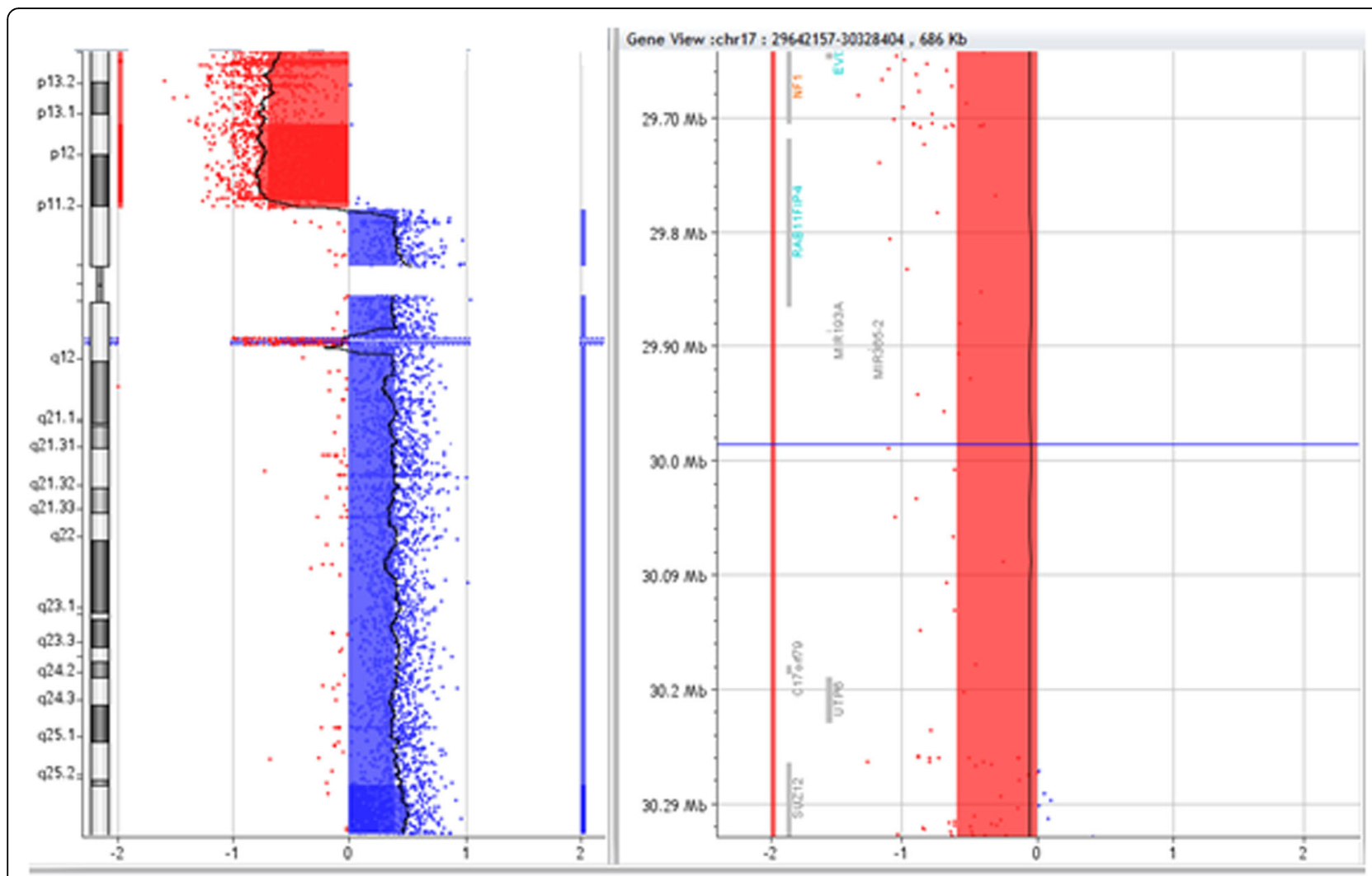

Fig. 6 aCGH characterized losses in 17p13.3-17p11.2 and 17q11.2-17q11.2 regions and gains in 17p11.2-17p11.1, 17q11.1-17q11.2 and 17q11.2$17 q 12.2$ regions. These observations were compatible with the FISH results and their locations according to the Genome Reference Consortium human genome (build 37) (GRCh37)/Human Genome Issue 19 (available from https://genome.ucsc.edu)

Table 2 Summary of CNAs detected by aCGH

\begin{tabular}{|c|c|c|c|}
\hline Chromosome & Cytobands & GRCH37/hg19 & Size of imbalance $[\mathrm{Mb}]$ \\
\hline$\overline{C h r .1}$ & del(1)(p36.33p36.22) & chr1:811,042-15,945,281 & 15.2 \\
\hline \multirow[t]{2}{*}{ Chr. 3} & $\operatorname{dup}(3)(q 12.2 q 12.2)$ & chr3:100,360,692-100,444,109 & 0.8 \\
\hline & dup(3)(q26.1q29) & chr3:163,428,815-198,007,542 & 34.5 \\
\hline Chr. 4 & $+4,+4$ & +4 & 191.1 \\
\hline Chr. 6 & +6 & +6 & 171.1 \\
\hline \multirow[t]{2}{*}{ Chr. 11} & del(11)(q14.2q14.3) & $\operatorname{chr11:88,758,551-90,262,511}$ & 1.5 \\
\hline & dup(11)(q24.3q25) & chr11:128,741,710-134,945,165 & 6.2 \\
\hline \multirow[t]{2}{*}{ Chr. 12} & del(12)(p13.3p11.2) & chr12:189,587-28,540,069 & 28.6 \\
\hline & $\operatorname{dup}(12)(p 11.2 q 12.2)$ & chr12:29,301,936-133,783,697 & 104.5 \\
\hline Chr. 14 & $\operatorname{del}(14)(q 24.3 q 24.3)$ & chr14:78,947,104-78,999,179 & 0.52 \\
\hline \multirow[t]{3}{*}{ Chr. 15} & del(15)(q14q14) & chr15:35,834,701-38,130,638 & 2.3 \\
\hline & del(15)(q21.1q21.1) & chr15:45,686,828-49,092,091 & 3.4 \\
\hline & $\operatorname{del}(15)(q 23 q 24.2)$ & chr15:69,669,842-75,954,617 & 6.3 \\
\hline \multirow[t]{5}{*}{ Chr. 17} & del(17)(p13.3p11.2) & chr17:6011-16,229,582 & 16.2 \\
\hline & $\operatorname{dup}(17)(p 11.2 p 11.1)$ & chr17:16,387,310-22,226,321 & 5.8 \\
\hline & $\operatorname{dup}(17)(q 11.1 q 11.2)$ & chr17:25,300,199-29,639,240 & 4.3 \\
\hline & del(17)(q11.2q11.2) & chr17:29,642,157-30,328,404 & 0.7 \\
\hline & $\operatorname{dup}(17)(q 11.2 q 12.2)$ & chr17:30,426,721-81,044,553 & 50.6 \\
\hline Chr. 19 & $\operatorname{del}(19)(q 13.2 q 13.31)$ & chr19:43,242,795-43,629,732 & 0.4 \\
\hline Chr. X & $-x$ & $-x$ & 155.0 \\
\hline
\end{tabular}



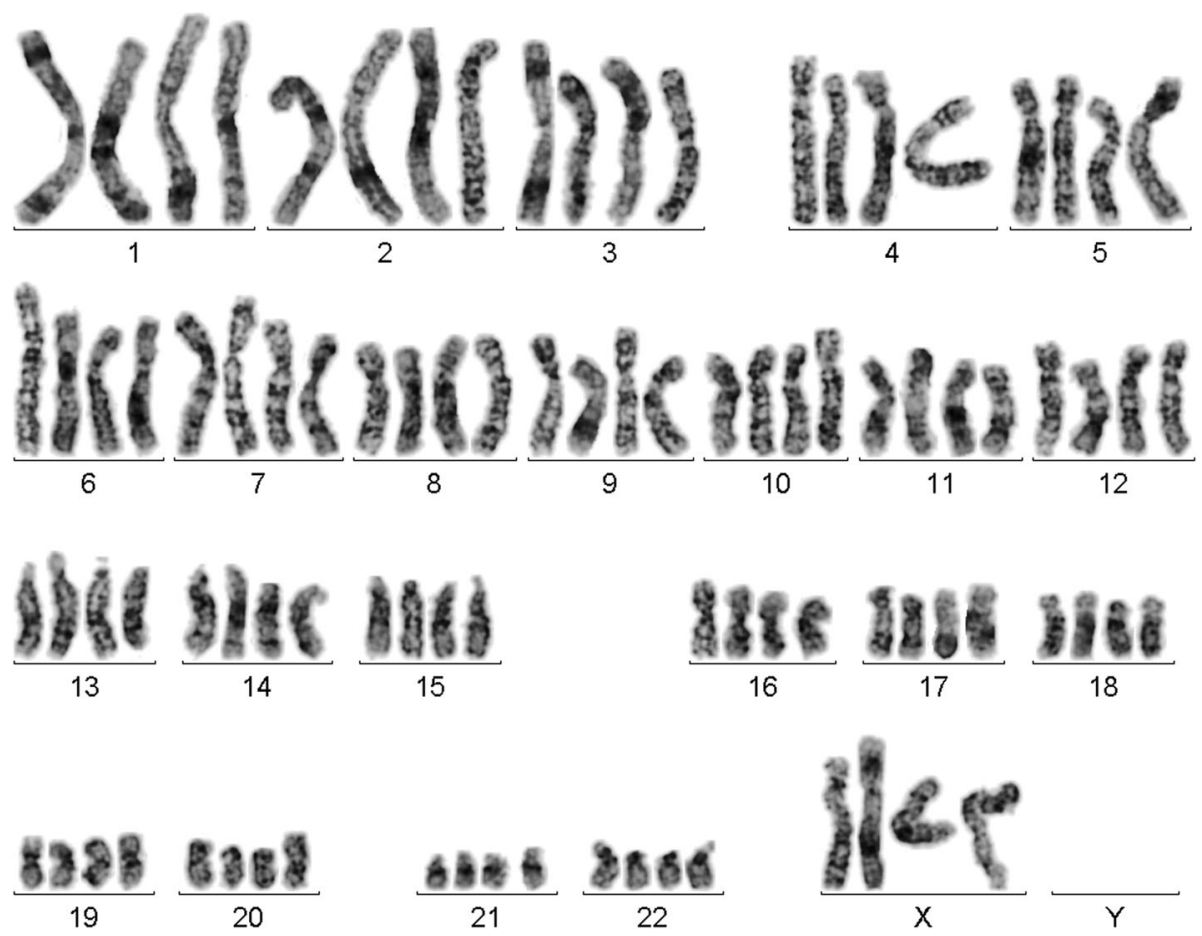

Fig. 7 GTG-banding in secondary AML-M6 revealed a tetraploid karyotype in 20\% of the analyzed cells

morphologically characterized AML cases were FAB types M2, M4, or M5 [14]. However, HH and tetraploidy was associated with poor outcome, i.e. median OS of and tetraploidy was 1.4 and for $\mathrm{HH}$ patients 0.6 years, which is in a similar range of CK patients with AML
[14]. However, $\mathrm{HH}$ and tetraploidy patients with only numerical changes have a median OS of 1.0 year, while OS was 1.1 years for $\mathrm{HH}$ and tetraploidy patients with known non-adverse structural aberrations compared to 0.8 years for those patients with known adverse
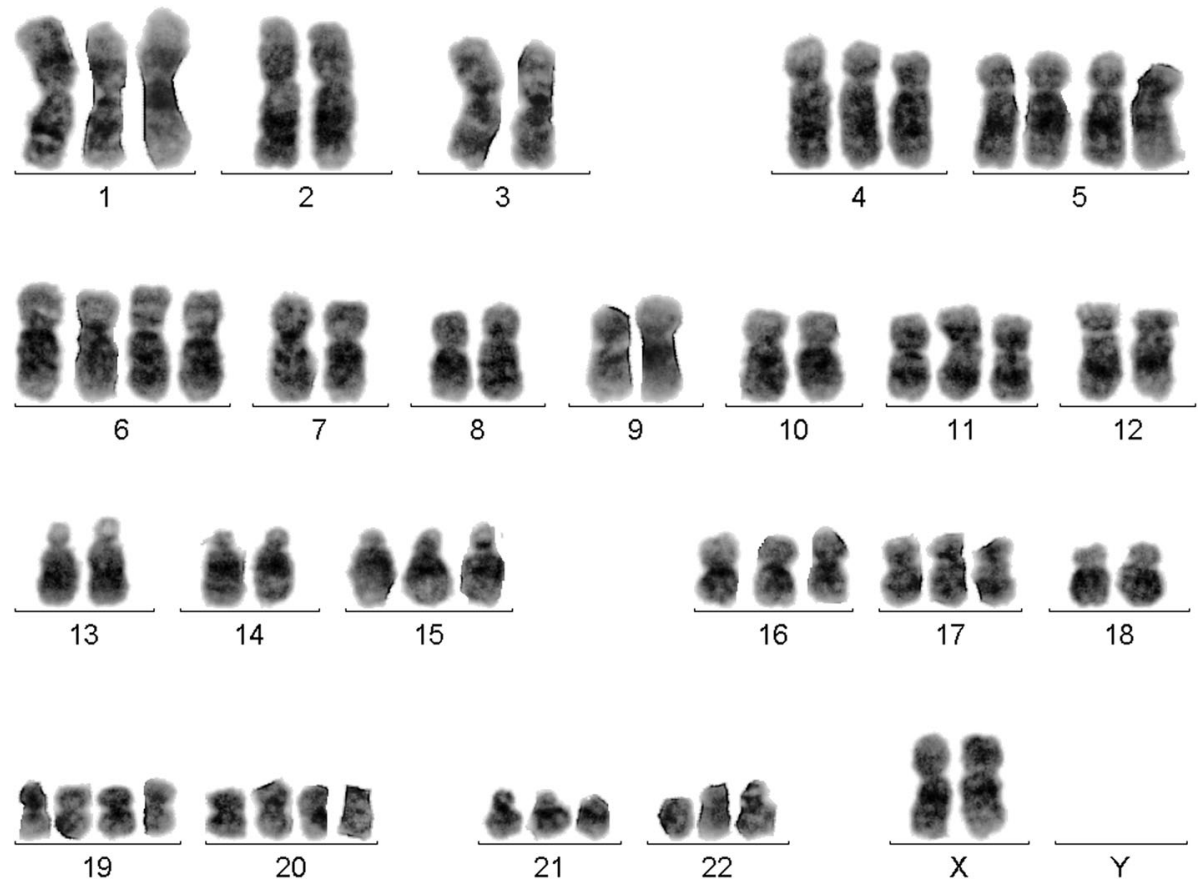

Fig. 8 GTG-banding secondary AML-M6 revealed a hyperdiploid karyotype in 10\% of the analyzed cells 
abnormalities [14]. Additionally, AML patients with $\geq 3$ three unrelated aberrations had a worse outcome than normal karyotype patients [19]. Thus, it was repeatedly suggested in contrast to main stream $[1,5,6]$, to reclassify AML patients in risk categories according to chromosomal aberrations rather than e.g. only HH $[11 ; 18]$. Stölzel et al. [19] proposed to distinguish $\mathrm{HH}$ patients with up to three aberrations without specific adverse-risk abnormalities, from those with more than 4 aberrations.

Concerning aberrations observed in the present case there was specifically in AML-M1 monoallelic losses for TP53, ETV6, BRCA1 genes and or gain of copy numbers for EVI1 (ecotropic viral integration site-1) gene. TP53 gene mutation is observed in approximately $5-10 \%$ of all AML cases, occurring frequently in elderly subjects and cases with FAB classification M6, as well as in cases with CK; it is associated with unfavorable prognosis [21]. Aberrant expression of EVI1 gene occurs in approximately 6$8 \%$ of AML cases and has been associated with poor treatment outcome [22, 23]. The EVI1 gene maps to chromosomal band 3q26.2 and was first identified to be aberrantly upregulated in almost all AML cases with $\mathrm{t}(3 ; 3)(\mathrm{q} 21 ; \mathrm{q} 26.2)$ [17] or inv.(3)(q21q26.2) [24, 25]. In our case with the $\mathrm{t}(1 ; 3)(\mathrm{p} 36.21 ; \mathrm{p} 26.2)$, the EVI1 locus at $3 \mathrm{q} 26$ is translocated to PRDM16 (MEL1; MDS1/EVI1-like-1) at 1p36, being highly homologous to EVI1 (PRDM3) [26]. In concordance with the conditions seen in the present case $\mathrm{t}(3 ; \mathrm{v})(\mathrm{q} 26 ;$;) translocation was associated with younger age AML; here, the complete remission rate has been reported to be $<50 \%$ and long-term OS $<10 \%$ [25].

According to the literature the here observed, we report the first AML-M1 case relapsing to a completely independent biclonal secondary AML-M6 case. Adverse outcome of the case may be partially caused by adverse mutations in AML-M1 like TP53 deletion and translocation $\mathrm{t}(1 ; 3)$ (p36.2;p26.2) involving EVI1 gene, but also by $\mathrm{HH}$. ICE therapy might have been helpful here, however, due to interrupted treatment this cannot be finally assessed.

\begin{abstract}
Abbreviations
aCGH: Array comparative genomic hybridization; aMCB: Array-proven multicolor banding; AML: Acute myeloid leukemia; BM: Bone marrow; CK: Complex karyotype; CSF: Cerebrospinal fluid; CT: Computer tomographic; DAPI: 4',6diamino-2-phenylindole; ELN: European Leukemia Net; FAB: French American British; FCM: Flow cytometric; FISH: Fluorescence in situ hybridization; HGB: Hemoglobin level; HH: High hyperdiploidy; OS: Overall survival; PB: Peripheral blood; PLT: Platelet count; PTT: Partial thromboplastin time; RBC: Red blood cells; WBC: White blood cells; WCP: Whole chromosome painting
\end{abstract}

\section{Acknowledgements}

We thank Prof. I. Othman, the Director General of Atomic Energy Commission of SYRIA (AECS) and Dr. N. Mirali, Head of Molecular Biology and Biotechnology Department for their support.

\section{Funding}

There was no funding available for this research.

Availability of data and materials

All relevant data and material is included in this publication.

\section{Authors' contributions}

AW, SA and WA performed banding cytogenetics; SS and RM provided the clinical data and the chemotherapy plan; AA did the immunophenotyping; AW, SA and TL performed the molecular cytogenetic analyses; TL and $\mathrm{MO}$ performed the $\mathrm{aCGH} ; \mathrm{AW}$ and $\mathrm{TL}$ drafted the paper and all authors worked on the final version of the paper. All authors read and approved the final manuscript.

\section{Ethics approval and consent to participate}

Study procedures were reviewed and approved by the ethical committee of the Atomic Energy Commission, Damascus, Syria Review Board. Written informed consent was obtained from all subjects prior to participation.

\section{Consent for publication}

Written informed consent was obtained from the patient's mother for publication of this case report and accompanying images. A copy of the written consent is available for review by the Editor-in-Chief of this journal.

\section{Competing interests}

The authors declare that they have no competing interests.

\section{Publisher's Note}

Springer Nature remains neutral with regard to jurisdictional claims in published maps and institutional affiliations.

\section{Author details}

'Department of Molecular Biology and Biotechnology, Human Genetics Division, Atomic Energy Commission, Damascus, Syria. ${ }^{2}$ Department of Molecular Biology and Biotechnology, Mammalians Biology Division, Atomic Energy Commission, Damascus, Syria. ${ }^{3}$ Institute of Human Genetics, Jena University Hospital, Jena, Germany. ${ }^{4}$ Department of

Haematology-transplantation, Tishreen Hospital, Damascus, Syria.

Received: 26 April 2018 Accepted: 9 August 2018

Published online: 31 August 2018

\section{References}

1. Grimwade D, Hills RK, Moorman AV, Walker H, Chatters S, Goldstone AH, et al. Refinement of cytogenetic classification in acute myeloid leukemia: determination of prognostic significance of rare recurring chromosomal abnormalities among 5876 younger adult patients treated in the United Kingdom Medical Research Council trials. Blood. 2010;116:354-65.

2. Schoch C, Kern W, Kohlmann A, Hiddemann W, Schnittger S, Haferlach T. Acute myeloid leukemia with a complex aberrant karyotype is a distinct biological entity characterized by genomic imbalances and a specific gene expression profile. Genes Chromosomes Cancer. 2005:43:227-38.

3. Dohner H, Estey EH, Amadori S, Appelbaum FR, Buchner T, Burnett AK, et al. Diagnosis and management of acute myeloid leukemia in adults: recommendations from an international expert panel, on behalf of the European LeukemiaNet. Blood. 2010;115:453-74.

4. Mrozek K, Marcucci G, Nicolet D, Maharry KS, Becker H, Whitman SP, et al. Prognostic significance of the European leukemiaNet standardized system for reporting cytogenetic and molecular alterations in adults with acute myeloid leukemia. J Clin Oncol. 2012;30:4515-23.

5. Döhner H, Estey E, Grimwade D, Amadori S, Appelbaum FR, Büchner T, et al. Diagnosis and management of AML in adults: 2017 ELN recommendations from an international expert panel. Blood. 2017;129:424-47.

6. Grimwade D, Walker H, Oliver F, Wheatley K, Harrison C, Harrison G, et al. The importance of diagnostic cytogenetics on outcome in AML: analysis of 1,612 patients entered into the MRC AML 10 trial. The medical research council adult and children's leukaemia working parties. Blood. 1998;92: 2322-33.

7. Byrd JC, Mrozek K, Dodge RK, Carroll AJ, Edwards CG, Arthur DC, et al. Pretreatment cytogenetic abnormalities are predictive of induction success, cumulative incidence of relapse, and overall survival in adult patients with de novo acute myeloid leukemia: results from Cancer and leukemia group B (CALGB 8461). Blood. 2002;100:4325-36.

8. Breems DA, Van Putten WL, De Greef GE, Van Zelderen-Bhola SL, GerssenSchoorl KB, Mellink CH, et al. Monosomal karyotype in acute myeloid leukemia: a better indicator of poor prognosis than a complex karyotype. J Clin Oncol. 2008;26:4791-7. 
9. Iyer RV, Sait SN, Matsui S, Block AW, Barcos M, Slack JL, et al. Massive hyperdiploidy and tetraploidy in acute myelocytic leukemia and myelodysplastic syndrome. Cancer Genet Cytogenet. 2004;148:29-34.

10. Luquet I, Laï JL, Barin C, Baranger L, Bilhou-Nabera C, Lippert E, et al. Hyperdiploid karyotypes in acute myeloid leukemia define a novel entity: a study of 38 patients from the Groupe francophone de Cytogenetique Hematologique (GFCH). Leukemia. 2008;22:132-7.

11. Chilton L, Hills RK, Harrison CJ, Burnett AK, Grimwade D, Moorman AV. Hyperdiploidy with 49-65 chromosomes represents a heterogeneous cytogenetic subgroup of acute myeloid leukemia with differential outcome. Leukemia. 2013:1-8.

12. AL-Achkar W, Wafa A, Nweder MS. A complex translocation $\mathrm{t}(5 ; 9 ; 22)$ in Philadelphia cells involving the short arm of chromosome 5 in a case of chronic myelogenous leukemia. J Exp Clin Cancer Res 2007;26:411-415.

13. McGowan-Joran J, Simons A, Schmid MS. ISCN 2016: an international system of human Cytogenomic nomenclature. Unionville, CT, USA: S. Karger Publications, Inc; 2016.

14. Othman MA, Grygalewicz B, Pienkowska-Grela B, Rincic M, Rittscher K, Melo JB, Carreira IM, Meyer B, Marzena W, Liehr T. Novel cryptic rearrangements in adult B-cell precursor acute lymphoblastic leukemia involving the MLL gene. J Histochem Cytochem. 2015;63:384-90.

15. Stewart CC, Stewart SJ. Current protocols in cytometry, unit 6.2.1-6.2.18. Inc.: John Wiley \& Sons; 1997.

16. Craig FE, Foon KA. Flow cytometric immunophenotyping for hematologic neoplasms. Blood. 2008;111:3941-67.

17. Mitelman F, Johansson B, Mertens F, editors. Mitelman database of chromosome aberrations and gene fusions in cancer (2017). http://cgap.nci. nih.gov/Chromosomes/Mitelman [accessed 29.04.2018].

18. Stölzel F, Mohr B, Kramer M, Oelschlägel U, Bochtler T, Berdel WE, et al. Karyotype complexity and prognosis in acute myeloid leukemia. Blood Cancer J. 2016;6:e386.

19. Harrison MT, Gelly K. An unusual presentation of secondary AML. Blood. 2016:128:2867.

20. Lazarevic V, Rosso A, Juliusson G, Antunovic P, Rangert-Derolf $\AA$, Lehmann S, et al. Prognostic significance of high hyperdiploid and triploid/tetraploid adult acute myeloid leukemia. Am J Hematol. 2015;90:800-5.

21. Stengel A, Kern W, Haferlach T, Meggendorfer M, Fasan A, Haferlach C. 2016 the impact of TP53 mutations and TP53 deletions on survival varies between AML, ALL, MDS and CLL: an analysis of 3307 cases. Leukemia. 2017:31:705-11.

22. Lugthart $S$, van Drunen $E$, van Norden $Y$, van Hoven A, Erpelinck CA, Valk PJ, et al. High EVI1 levels predict adverse outcome in acute myeloid leukemia: prevalence of EVI1 overexpression and chromosome 3q26 abnormalities underestimated. Blood. 2008:111:4329-37.

23. Haas K, Kundi M, Sperr WR, Esterbauer H, Ludwig WD, Ratei R, et al. Expression and prognostic signifi cance of diff erent mRNA 5'-end variants of the oncogene EVI1 in 266 patients with de novo AML: EVI1 and MDS1/ EVI1 overexpression both predict short remission duration. Genes, Chromosomes Cancer. 2008;47:288-98.

24. Morishita K, Parganas E, William CL, Whittaker MH, Drabkin H, Oval J, et al. Activation of EVI1 gene expression in human acute myelogenous leukemias by translocations spanning 300-400 kilobases on chromosome band 3q26. Proc Natl Acad Sci U S A. 1992;89:3937-41.

25. Lugthart S, Groschel S, Beverloo HB, Kayser S, Valk PJM, van Zelderen-Bhola SL. Clinical, molecular, and prognostic significance of WHO type $\operatorname{inv}(3)(q 21 q 26.2) / t(3 ; 3)(q 21 ; q 26.2)$ and various other $3 q$ abnormalities in acute myeloid leukemia: A study of 6,500 cases of AML. J Clin Oncol. 28 3890-3898.

26. Barjesteh van Waalwijk van Doorn-Khosrovani S, Erpelinck C, Lowenberg B, Delwel R. Low expression of MDS1-EVI1-like-1 (MEL1) and EV11-like-1 (EL1) genes in favorable-risk acute myeloid leukemia. Exp Hem. 2003;31:1066-1072

\section{Ready to submit your research? Choose BMC and benefit from}

- fast, convenient online submission

- thorough peer review by experienced researchers in your field

- rapid publication on acceptance

- support for research data, including large and complex data types

- gold Open Access which fosters wider collaboration and increased citations

- maximum visibility for your research: over $100 \mathrm{M}$ website views per year

At BMC, research is always in progress.

Learn more biomedcentral.com/submissions 